\section{Kastamonu Eğitim Dergisi Kastamonu Education Journal}

Eylül 2019 Cilt:27 Sayı:6

kefdergi.kastamonu.edu.tr
Başvuru Tarihi/Received: 12.04.2018

Kabul Tarihi/Accepted: 15.03.2019

DOI: $10.24106 /$ kefdergi.2987

\title{
Öğretmenlerin Yaratıcılıkları ile Empatik Becerilerinin Bazı Değişkenlere Göre İncelenmesi
}

\section{Examination of Teachers' Creativity and Empathic Abilities in Terms of Some Variables}

\section{Öz}

\author{
Güneş SALI ${ }^{1}$
}

Okul öncesi öğretmenleri ile sınıf öğretmenlerinin yaratıcılıklarının bazı değişkenlere göre incelenmesi amacıyla yapılan bu araştırmada betimsel yöntemlerden biri olan ilişkisel tarama modeli kullanılmıştr. Araştırmanın çalışma grubunu 65 sınıf öğretmeni, 65 okulöncesi öğretmeni olmak üzere toplam 130 öğretmen oluşturmuştur. Araşttrmada veriler Genel Bilgi Formu, Torrance Yaratıcı Düşünce Ölçeği Şekil Form A Testi ile toplanmıştr. Verilerin analizinde Kolmogorov Smirnov (K-S) Testi, Tek Değişkenli Kovaryans Analizi (ANCOVA) ve regresyon analizi yapılmıştr. ANCOVA sonuçları yaratıcılık alt boyutlarından akıcılık, orijinallik, başlıkların soyutluğu ve erken kapamaya direnç alt boyutlarından alınan yaşa göre düzeltilmiş puanlarında branşa göre anlamlı bir farklılık olmadığını göstermiştir. Ancak zenginleştirme alt boyutunda branşa göre anlamlı bir farklılık bulunmuştur( $p<.001)$. Okul öncesi öğretmenlerinin zenginleştirme ( $\left.\overline{\times}_{D}: 13.06\right)$ puanlarının, sınıf öğretmelerinin zenginleştirme $\left(\bar{x}_{D}: 10.85\right)$ puanlarından anlamlı şekilde yüksek olduğu görülmüştür. Yapılan çoklu regresyon analizinde, yaratıcılığın alt boyutlarının tamamının empatik beceriyi yordadığı görülmüştür $(F(5,124)=69.01, p<.001, R=.858, R 2=.736, R 2$ adj=.725). Verilerin test edilmesinde .05 anlamlılık düzeyi dikkate alınmıştır.

Anahtar Kelimeler: Okulöncesi öğretmeni, sınıf öğretmeni, yaratıcılık, empati

\section{Abstract}

In this study conducted to examine the creativity of preschool and classroom teachers in terms of some variables, correlational screening model, one of the descriptive methods, was used. The study group consisted of a total of 130 teachers, including 65 classroom teachers and 65 preschool teachers. Data were collected by using General Information Form, Torrance Creative Thought Scale Figure Form A Test. Kolmogorov Smirnov (KS) Test, Univariate Covariance Analysis (ANCOVA) and regression analysis were performed in the analysis of the data. ANCOVA results showed that there was no significant difference in age-adjusted scores obtained from the subscales of fluency, originality, abstraction of titles, and early-closure resistance among creativity subscales in terms of the branch. However, a significant difference was found in the enrichment subscale according to the branch $(p<.001)$. The enrichment $\left(\bar{x}_{D}: 13.06\right)$ scores of pre-school teachers were found to be significantly higher than the enrichment $(\overline{\times}$ D:10.85) scores of classroom teachers. In the multiple regression analysis, it was seen that all of the subscales of creativity predicted empathic ability $(F(5,124)=69.01, p<.001, R=.858, R 2=.736, R 2 a d j=.725)$. The significance level of .05 was taken into account in testing the data.

Key Words: Preschool teacher, classroom teacher, creativity, empathy

1. Yozgat Bozok Üniversitesi, Eğitim Fakültesi, Temel Eğitim Bölümü, Yozgat, Türkiye; https://orcid.org/0000-0001-5719-8618 


\section{Extended Abstract}

Exploration and development of creativity characteristics is directly related to the encouragement of creativity by the circle and the demonstration of the best examples. In this sense, the importance of school and classroom environment and the teacher which are the most effective on the child after the family cannot be deniable (Töremen, 2003). According to Torrance (1987), in order to raise creative children, teachers need to create teaching environments where they can push the limits of the mind (Torrance, 1987). An overly restrictive, inhibiting, coercive, and authoritarian environment hinders the development of creative thinking.

It is important for teachers to be inspirational and prepare a guiding environment for producing new things by giving children more thought (Töremen, 2003), to watch their steps at each stage, work with them, and encourage them in their successes in order to develop creativity. The fact that children are tolerant of new and different ideas to their thoughts and teachers and students find creative ways together can increase the success (Hamza and Farrow, 2000). Development of creativity and creation of appropriate creative learning environments can be provided by creative teachers (Gültekin, 2004). According to some authors, creative teachers provide a learning opportunity that is very likely to perceive uncertainty and failure for creative endeavor by both taking risk and exhibiting their own creative interactions (Halpin, 2003).

According to Yavuzer (1996), a positive classroom environment depends on the nature of the teacher's relationships with the students. Teacher's empathic understanding will determine the nature of this relationship. Teacher's creativity can make it easier to empathize with the child. As a matter of fact, it is stated that creativity is an important feature to empathize (Dökmen, 1996). Teachers with high emphatic skills may have a healthier, more efficient and more reassuring communication with their students. The child can focus on, produce, and develop creativity to the extent that he feels safe. Indeed, it is expressed that pressure, control and criticism are among the behaviors that affect negatively the creativity of the child (Kemple and Nissenberg, 2000). The correlation between children's ability to develop creativity and empathic skills explains the role of the successful use of social creativity on empathy. Creative artistic activities such as painting and solo music also improve children's empathic skills (Fishkin, Cramond, and Olszewski-Kubilius (1999). Thus, it can be said that empathic skill supports the development of creativity and there is a correlation between creativity and empathic skill in children. Additionally, social creativity can also contribute positively to empathic skill. As a result, it can be asserted that creativity interacts with empathy. Kyzer (2001) states that many features and characteristics defined in Torrance's creative expressive features are often defined as tendencies related to highly empathic persons. Two of many factors that contribute to resolve life complexities successfully and to cope with them are creativity and empathy (Kyzer, 2001).

Occupational competences of teachers with low creativity level, inadequate communication and empathic skilIs may be considered to be low. This situation, which would not be desirable in an educational environment, can adversely affect the development of children. Thus, the determination of creativity and empathic tendency levels of teachers can help to raise teachers with high creativity and empathic skills. For this reason, it is important to examine the creativities and empathic skills of teachers in this study.

In this study, it was aimed to examine the creativity of preschool teachers and class teachers according to some variables. The sample group of this study consisted of a total of 130 teachers including 65 preschool teachers working in kindergartens of primary schools in city center of Yozgat, vocational high school application kindergartens and independent kindergartens as well as and 65 class teachers working in primary schools. The General Information Form, the Torrance Test of Creative Thinking, the Form A Test, and the Empathy Skill Scale Form B were used as data collection tool in the study. Kolmogorov Smirnov (KS) Test, Univariate Covariance Analysis (ANCOVA) and regression analysis were performed in the analysis of the data. ANCOVA results showed that there was no significant difference in age-adjusted scores obtained from the subscales of fluency, originality, abstraction of titles, and early-closure resistance among creativity subscales in terms of the branch. However, a significant difference was found in the enrichment subscale according to the branch ( $p<.001)$. The enrichment ( $D: 13.06)$ scores of the preschool teachers were found to be significantly higher than the enrichment (D: 10.85) scores of the class teachers. In the multiple regression analysis, it was observed that all of the subscales of creativity predicted the empathic skills $(F(5,124)=69.01, p<.001, R=.858, R 2=.736, R 2 a d j=.725)$. The significance level of .05 was taken into account in testing the data. The following suggestions can be made in accordance with the results obtained in this study conducted for the purpose of examining the creativity and empathic skills of preschool teachers and class teachers;

Creativity education programs can be organized for both preschool teachers and class teachers. Likewise, empathy training programs can be organized for teachers in both branches. For Creativity and development of class teacher education programs, lessons such as drama, etc. can be involved. In future studies, the variation in the creativity of the preschool teachers and class teachers depending on the time can be examined and longitudinal studies can be organized. 


\section{Giriş}

Öğretmenler geçmişte olduğu kadar, günümüzde de çocukların yakınsal gelişim alanlarında önemli roller üslenmektedir. Çocuklar için öğretmenleri önemli rol modeller olabilmektedir. Öğretmenler, çocukların potansiyel özelliklerini ortaya çıkaracak ortamlar sunarak çok yönlü gelişimlerine önemli katkılar sağlayabilmektedirler. Yaratıcılık, çocukta erken dönemlerden itibaren uygun ortamlar sunularak gelişiminin desteklenmesi gereken önemli bir özelliktir.

Yaratıcılık özelliklerinin ortaya çıkarılması ve geliştirilmesi, çevrenin yaratıcılı̆̆ teşvik etmesi ve en iyi örneklerin gösterilmesi ile doğrudan ilişkilidir. Bu anlamda çocuğun üzerinde aileden sonra en etkili olan okul ve sınıf ortamının ve öğretmenin önemi yadsınamaz (Töremen, 2003). Torrance'e göre (1987) yaratıcı çocuklar yetiştirebilmek için öğretmenlerin, zihnin sınırlarını zorlayabileceği öğretim ortamları oluşturmaları gerekmektedir (Torrance, 1987). Aşırı kısıtlayıcı, engelleyici, kalıplayıcı ve otoriter bir ortam, yaratıcı düşünmenin gelişimini engellemektedir. Torrance, Minnesota Araştrrmalarında yaratıcı öğretmen-yaratıcı öğrenci ilişkisinin çok yüksek olduğunu ortaya koymuştur (San, 2004).

Öğretmenlerin ilham verici ve çocukları daha çok düşündürerek yeni şeyler üretme konusunda yönlendirici bir ortam hazırlaması (Töremen, 2003), her aşamada onların adımlarını izlemesi, onlarla birlikte çalışması ve başarılarında onlara cesaret vermesi yaratıcılığın geliştirilmesinde oldukça önemlidir. Çocukların düşüncelerine yeni ve farklı fikirlerine hoşgörülü olması, öğretmen ve öğrencilerin birlikte yaratıcı yollar bulması başarıyı arttırabilmektedir (Hamza ve Farrow, 2000). Uygun öğretim yaşantıları sunulduğunda ve uygun teknikler kullanıldığında yaratıcılık geliştirilebilir. $\mathrm{Bu}$ anlamda temel yaratıcı teknikler önemli olmakla birlikte, öğretmenlerin yaratıcılığı engelleyen ve harekete geçiren sebepleri bilmeleri de bir zorunluluktur. Öğrencilere yaratıcılığı öğretme konumundaki öğretmenlerin, kendilerinin de yaratıcı olmayı öğrenmeleri gerekmektedir (Torrance, 1987). Yaratıcılığın geliştirilmesi ve uygun yaratıcı öğrenme ortamlarının oluşturulması yaratıcı öğretmenlerle sağlanabilir (Gültekin, 2004). Öğretmen çocukların yaratıcılıklarını geliştirirken, onların özgüvenlerini ve akademik bilgisini de geliştirebilir, çünkü öğretmen sınıfta yaratıcılığın kazanabileceği faydaları en üst düzeye çıkarabilir (Kaufman ve Beghetto, 2013). Bazı yazarlara göre yaratıcı öğretmenler, hem risk alarak hem de kendi yaratıcı etkileşimlerini sergileyerek, yaratıcı çaba için belirsizlik ve başarısızlığı algılama olasılığı yüksek bir öğrenme firsatı sağlarlar (Halpin, 2003).

Yavuzer'e (1996) göre olumlu bir sınıf ortamı, öğretmenin öğrencileriyle kuracağı ilişkilerin niteliğine bağlıdır. Bu ilişkinin niteliğini ise öğretmenin empatik anlayışı belirleyecektir. Öğretmenin yaratıcılığı çocuk ile empati kurmayı kolaylaştırabilir. Nitekim yaratıcılığın, empati kurabilmek için gerekli olan önemli bir özellik olduğu belirtilmektedir (Dökmen, 1996). Empatik beceri kişilerarasında sağlıklı iletişimin kurulmasında önemli bir role sahiptir (Kalliopuska, 1992). Empatik becerisi yüksek olan öğretmenin, öğrencisi ile kuracağı iletişim daha sağlıklı, daha etkili ve daha güven verici olabilir. Çocuk kendini güvende hissedebildiği ölçüde etkinliğe odaklanabilir, üretebilir, yaratıcılığı gelişebilir. Nitekim baskı, kontrol ve eleştirinin, çocuğun yaratıcılığını olumsuz yönde etkileyen davranışlar arasında yer aldığı ifade edilmektedir (Kemple ve Nissenberg, 2000). Broinowski (2002) yaptı̆ı araştırmada, okulöncesi eğitim programının kalitesi ve öğretmenlerin yaratıcılık düzeylerini incelemiştir. Bu çalışmanın sonunda okulöncesi öğretmeninin sahip olduğu sezgi ve hayal gücü ile çocukların yaratıcılığı ve hayal gücü arasında, ayrıca kaliteli bir okulöncesi eğitim programı arasında pozitif bir ilişki olduğu sonucuna ulaşmıştır. Eğitimcinin yaratıcılık yeteneğinin çocukların eğitim hayatını zenginleştirmede en önemli faktör olduğu görülmüştür. Çocuklarda yaratıcılığı geliştirmek ile empati kurma becerileri arasındaki ilişki, sosyal yaratıcılı̆̆ı başarılı kullanımının empati üzerindeki rolünü açıklamaktadır. Resim, solo müzik gibi yaratıcı sanatsal etkinlikler de çocukların empatik becerilerini geliştirmektedir (Fishkin, Cramond, ve Olszewski- Kubilius (1999). Böylece çocuklarda yaratıcılığı geliştirme becerisi ile empatik beceri arasında bir ilişki olduğu, empatik becerinin yaratıcılığın gelişimini desteklediği söylenebilir. Aynı zamanda sosyal yaratıcılık da empatik beceriye olumlu katkı sağlayabilir. Sonuç olarak yaratıcılık ile empatinin karşılıklı etkileşim içinde olduğu söylenebilir. Nitekim Kyzer, (2001) Torrance'nın yaratıcı güçlü ifade özelliklerinde tanımlanan birçok özelliğin ve karakteristik özelliklerin de genellikle oldukça empatik kişilerle ilgili eğilimler olarak tanımlandığını ifade etmektedir. Kişinin yaşamın karmaşalarını başarıyla çözme ve baş etmede katkı sağlayan pek çok faktörlerden ikisi yaratıcılık ve empatidir (Kyzer, 2001). Tardif ve Sternberg (1991) de yaratıcılık ve empatinin farklı şeyler olmadığı görüşünde birleşirler (Akt. Kyzer, 2001). Carlozzi, Bull, Eells ve Hurlburt (1995)'ın, üniversite mezunu 56 kişi üzerinde empati ile yaratıcılık ve dogmatizm arasındaki ilişkinin incelenmesi amacıyla yaptıları araştırma sonucunda, (önceki araştırmacıların, daha yaratıcı bireylerin, daha az yaratıcı bireylerden daha empatik oldukları tezini destekler şekilde) yaratıcılık ile empati puanları arasında pozitif ve yüksek bir ilişki olduğunu, empati ile dogmatizm arasında ise negatif bir ilişki olduğunu belirlemişlerdir. Yaratıcılık ile empati arasındaki doğrudan ilişkinin incelendiği bu araştırmaların yanı sıra, yaratıcılık ile empati arasında dolaylı olarak ilişkinin olduğunu ortaya koyan pek çok araştırma yapılmıştır. Empati ve resim (Wallace, 1998), empati ve dans (Kalliopuska, 1989), gibi ifade edici yaratıcı diğer aktiviteler arasındaki ilişkiyi ortaya koyan araştırmalar da bulunmaktadır. Diğer bazı yazarlar, şiir ve heykel gibi yaratıcı aktivitelerin, diğer kişiler ile iletişimi cesaretlendirmede araç olarak nasıl kullanılabileceğini açıklamışlardır (Bronson ve Schaub, 1996; Schrader ve Remer, 1980) Yaratıcılık, uyum sağlama becerisinde önemli bir özellik olarak görülmekte ve 
kişilerarası problemleri çözmede bireylerin yeni yolları keşfetmelerini kolaylaştırdığı ifade edilmektedir (Butcher ve Niec 2005; Köksal Akyol 2011; Oğuzkan, Demiral ve Tür, 1999; San, 1985).

Yurt içinde ve yurt dışında yapılan diğer araştırmalarda üniversite öğretim elemanlarının yaratıcılık kapasitelerinin (Cengizhan, 1997), öğretmenlerde denetim odağının problem çözmeye yönelik yaratııılıklarıyla ilişkisinin (Genç, 2000), okulöncesi öğretmenliği 1., 2. ve 3. sınıf öğrencilerinin yaratıcı düşünme becerilerinin (Çetingöz, 2002), okulöncesi eğitim programının kalitesi ve öğretmenlerin yaratıılık düzeylerinin (Broinowski, 2002), ilköğretimde görevli öğretmenlerin örgütsel bağılıklarıyla yaratıcılıkları arasındaki ilişkinin (Altın, 2010), okul öncesi öğretmenliği öğrencilerinin yaratıcılık ve problem çözme düzeyleri arasındaki ilişkinin (Zeytun, 2010), okul öncesi öğretmenleriyle okul öncesi öğretmen adaylarının yaratıcı düşünme beceri düzeyleri ve öğretmenlerde ve öğretmen adaylarında yaratıcı düşünceyi etkileyebilecek bazı faktörlerle arasındaki ilişkinin (Karaçelik, 2009) incelendiği görülmektedir. Yaratıcılık düzeyleri düşük, iletişim ve empati kurma becerileri yetersiz olan öğretmenlerin mesleki yeterliliklerinin de düşük olacağı düşünülebilir. Bir eğitim ortamında arzu edilmeyecek bu durum, çocukların gelişimini olumsuz etkileyebilir. Bu nedenle öğretmenlerin yaratıcılıklarının ve empatik eğilim düzeylerinin belirlenmesi, yaratıcılığı ve empati kurma becerisi yüksek öğretmenler yetiştirmede yarar sağlayabilir. Bu nedenle bu araştırmada öğretmenlerin yaratıcılıkları ile empatik becerilerinin incelenmesi önemli bulunmuştur. Çocuklarda geliştirilmesi gereken özellikleri onlara öğretme, yardım etme, danışmanlık ve model olma yoluyla geliştirecek olan en önemli kişiler, öğretmenlerdir. Bu süreçte, okul öncesi öğretmenlerinin ve sınıf öğretmenlerinin yaratıcılıklarının ve empatik becerilerinin bilinmesi çocuklara verilecek eğitimin kalitesi açısından da önemli görülmektedir.

\section{Araştırmanın Amacı}

Bu çalışmada okul öncesi öğretmenleri ile sınıf öğretmenlerinin yaratıcılıklarının bazı değişkenlere göre incelenmesi amaçlanmıştır. Bu amaç doğrultusunda aşağıda verilen araştırma sorularına yanıt aranmıştır.

1. Okul öncesi öğretmenleri ile sınıf öğretmenlerinin yaratıılık puanları ve empatik beceri puanları arasında anlamlı fark var mıdır?

2. Okul öncesi öğretmenlerinin ve sınıf öğretmenlerinde yaratıcılıkları, empatik becerilerini yordamakta mıdır?

\section{Yöntem}

\section{Çalışma Grubu}

$\mathrm{Bu}$ araştırmanın çalışma grubunu Yozgat il merkezindeki ilkokulların anasınıfları ile kız meslek lisesi uygulama anaokulunda ve bağımsız anaokullarında çalışan toplam 65 okulöncesi öğretmeni ile ilkokullarda çalışan toplam 65 sınıf öğretmeni olmak üzere toplam 130 öğretmen oluşturmuştur. Okul öncesi öğretmenlerinin tamamının kadın olması nedeni ile sınıf öğretmenleri de bu sayıya denk olacak şekilde, benzer demografik özelliklere sahip kadın öğretmenler arasından toplam 23 ilköğretim okulundan tesadüfi yöntem ile belirlenmiştir. Araştırma toplam 130 kadın öğretmen üzerinden yürütülmüştür. Araştırmaya katılan öğretmenlerin yaş aralığı 23 ila 45 arasında değişmekte olup ortalama yaşları 33.38 (S.S: 5.19)'dur. Araştırmaya katılan öğretmenlerin mesleki kıdemleri 1 ile 20 yıl arasında değişmekte olup ortalama mesleki deneyimleri 10.78 (S.S: 4.89)' dir. Araştırmaya katılan öğretmenlerin \% 90'ı evli, \% 10ıu bekardır. Yaratııılık demografik değişkenlerden etkilenebilecek bir değişken olduğundan örneklemi oluşturan sınıf öğretmenleri ve okul öncesi öğretmenleri yaş, mesleki kıdem ve medeni durum açısından karşılaştırılmıştır. Bu karşılaştırma sonucunda sınıf öğretmenlerinin okul öncesi öğretmenlerinden daha yaşlı $(t(117.61)=8.215, p<.001)$ ve daha fazla mesleki kıdeme sahip $(t(118.51)=8.876, p<.001)$ olduğu bulunmuştur. Ancak bekar okul öncesi öğretmenlerin oranının, bekar sınıf öğretmenlerinden anlamlı şekilde yüksek olduğu görülmüştür $\left(\chi^{2}(1, N=130)=4.19, p=.041\right)$.

\section{Veri Toplama Aracı}

Araştırmada veri toplama aracı olarak Genel Bilgi Formu, Torrance Yaratıcı Düşünce Ölçeği Şekil Form A Testi ve Empatik Beceri Ölçeği B Formu kullanılmıştır.

Genel Bilgi Formu: Araştırmacı tarafindan öğretmenler için geliştirilen genel bilgi formu, araştırmaya katılan öğretmenlerin okul adı, branşı, bulunduğu okulda kaç yıldır görev yaptığı, sınıflarındaki öğrenci sayısı, mesleki kıdemi, cinsiyeti, yaşı hakkındaki bilgilerin belirlenmesine yönelik sorular içermektedir.

Torrance Yaratıcı Düşünce Testi Şekil Form A: Torrance tarafindan 1966 yılında geliştirilen test, sözel ve şekilsel olmak üzere iki kısımdan oluşmaktadır. Sözel ve şekilsel testlerin A ve B formları olmak üzere kendi içerisinde dört farklı test bulunmaktadır. Torrance Yaratııı Düşünce sözel ve şekilsel testlerinde yer alan alt testler, sorun çözme için gerekli çok sayıda, olabildiğince farklı alanda ve oldukça az rastlanan ve yaratıcı güç gerektiren düşünceleri ortaya çıkarmayı amaç| Kastamonu Eğitim Dergisi, 27(6), 2019| 
layan sorular içermektedir. Bu çalışmada Şekil Form A kullanılmıştır.

Şekil Form A testinde yaratıcılık; Akıcılık, Orijinallik, Başlıkların Soyutluğu, Zenginleştirme ve Erken Kapanmaya Direnç alt boyutlarında değerlendirilmektedir. Akıcılık bir problem için birçok alternatif geliştirebilme çok sayıda fikir, düşünce ve çağrışım üretebilme, Orijinallik (Özgünlük) bir problem karsısında sıradan olmayan, farklı, benzersiz çözümler üretme yeteneği, eşsiz, rastlanmayan, akıllı düşünceler yaratma ya da yeni özel çözümler getirme, yeni, alışımamış ve az rastlanan fikirler üretme olarak tanımlanırken, zenginleştirme birinin fikrini hikâyesini veya çizimini geliştirme veya genişletme yeteneği verilen yalın bir uyaranı ayrıntılı ve özenli bir biçimde işleyip geliştirme, ayrıntılara girebilme, yanıtlar ekleme anlamında kullanılmaktadır. Başıılırın soyutluğu süreçlerin, işlemlerin sentezinin ve organizasyonun yapılabilmesi ile ilgilidir. En üst seviyede söz konusu bilginin özünü yoklayabilmek, önemli olanın ne olduğunu bilmek önemlidir. Bu tip bir başlık resme bakan kişinin, resmi daha derinliğine ve zengin bir biçimde görebilmesini sağlamaktadır. Erken kapamaya direnç mümkün olan bilgiyi göz önünde tutmayıp erkenden (premature) sonuçlara sıçrama eğilimi yerine, orijinal fikirleri mümkün kılan zihinsel atlamayı yapmaya yetecek kadar kapamayı geciktirip, zihnini açık tutabilmek anlamında kullanılmaktadır (Erlendsson, 1999; Öncü, 2003; Rein ve Rein, 2000; Torrance ve Goff, 1989).

Ölçeğin Şekil A formunda resim oluşturma, resim tamamlama ve paralel çizgiler olmaküzere üç alt test bulunmaktadır.

Resim Oluşturma: Verilen geometrik şeklin tamamlanarak yeni bir şeklin oluşturulması ve bu yeni şekil ile ilgili bir hikâye oluşturulması ya da bir isim verilmesi istenmektedir.

Resim Tamamlama: On adet yarım bırakılmış çizginin çocuk tarafindan yeni bir şekil hâline getirilmesi ve isimlendirilmesi istenmektedir.

Paralel Çizgiler: Aynı tür uyarana verilebilecek farklı yanıtların test edilmesi amaçlanmaktadır. Verilen otuz adet paralel çizgi ile yeni şekiller oluşturulması ve isimlendirilmesi istenmektedir.

Her üç test için (Resim Oluşturma, Resim Tamamlama, Paralel Çizgiler veya Daireler) puanlar duygusal ifadeler, hikâye anlatma, hareket ya da faaliyet, başlıkların açıklayıcılığı, tamamlanmamış şekillerin birleştirilmesi, tamamlanmamış çizgilerin sentezi, alışılmadık görselleştirme, içsel görselleştirme, sınırları uzatma veya geçme, mizah, hayal gücü zenginliği, hayal gücü renkliliği ve fantezi boyutlarında değerlendirilmektedir. Testin değerlendirilmesinde norm dayanaklı ölçüler ve kriter dayanaklı ölçüler olmak üzere iki ölçü dikkate alınmaktadır. Bu çalışmada norm dayanıklı ölçütler kullanılmıştır. Norm dayanaklı ölçüler; Akıcılık, Orijinallik, Başlıkların Soyutluğu, Zenginleştirme ve Erken Kapanmaya Direnç olmak üzere beş tanedir. Akıcılık puanı; resim tamamlama ve paralel çizgiler testinin, Orijinallik puanı; resim oluşturma, resim tamamlama ve paralel çizgiler testinin, Başlıkların Soyutluğu puanı; resim oluşturma ve resim tamamlama testinin, Zenginleştirme puanı, resim oluşturma, resim tamamlama ve paralel çizgiler testinin, Erken Kapanmaya Direnç puanı ise; resim tamamlama testinin farklı açılardan değerlendirilmesi sonucu elde edilmektedir (Aslan, 2001).

Torrance Yaratıcı Düşünce Ölçeği'nin sözel ve şekilsel kısımları Aslan (2001) tarafından Türkçeye uyarlanmıştır. Dil geçerliliği çalışması kapsamında İngilizce ve Türkçe test uygulamaları arasında tüm alt boyutlarında .50 ila .96 arasında değişen pozitif yönde yüksek düzeyde korelasyonlar bulunmuştur. Üniversite öğrencileri üzerinde bildirilen Cronbach Alpha güvenirlilik katsayıları .56 ila .84 arasında değişmektedir.

Torrance Yaratıcı Düşünce Ölçeği 'nin sözel ve şekilsel kısımları Aslan (2001) tarafindan Türkçeye uyarlanmış ve testin çevirisi, test maddelerinin Türkçeye adaptasyonu, Türkçeye çevirisinin geçerliği ve güvenirliği araştırılmıştır. İngilizce ve Türkçe test uygulamaları arasındaki korelasyon toplam şekilsel yaratııılık için yüksek düzeyde anlamlı çıkmıştı $(r=0.59)$. Elde edilen iç tutarlılık analizlerinde $r=0.38$ ile $r=0.89$ arasındadır. Okul öncesi grubunun en düşük puanı ise Cronbach alfa değeri olarak .50, en yüksek iç tutarlılık katsayısı .71 olarak belirlenmiştir. Geçerlik çalışmaları kapsamında ise iç geçerlik ve dış geçerlilik çalışmaları yapılmıştı. Kriter geçerliği başlı̆ı altında sıfat listesi, Wechsler Yetişkinler Formu ve Wonderlic Personel Testi (Genel Yetenek Testi) kullanılmış ve yapılan analizler sonucunda, testin tüm yaş grupları ve puan türleri için güvenilir olduğu görülmüştür (Aslan, 2001). Torrance yaratıclık testi sözel ve şekilsel formlar okul öncesinden üniversite mezunlarına kadar her kademede kullanılabilmektedir (Torrance, 1974; Aslan, 2001; Aslan ve Puccio, 2006). Ölçeğin bu araştrma kapsamında tekrar güvenirlik çalışması yapılmıştır. Torrance Yaratıcı Düşünce Ölçeği Şekil Form A Formu'nun Akıcılık alt boyut güvenirlik katsayısı (Alpha) 0.727 Orijinallik alt boyut güvenirlik katsayısı (Alpha) 0.725, Başlıkların soyutluğu alt boyut güvenirlik katsayısı (Alpha) 0.826, Zenginleştirme alt boyut güvenirlik katsayısı (Alpha) 0.826, Erken kapanmaya direnç alt boyut güvenirlik katsayısı (Alpha) 0.820, Toplam ölçek güvenirlik katsayısının (Alpha) 0.677olduğu belirlenmiştir. Elde edilen bu sonuçlar da, Torrance Yaratıcı Düşünce Ölçeği Şekil Form A Formu'nun güvenilir bir veri toplama aracı olduğu görüşünü destekler niteliktedir.

Empatik Beceri Ölçeği B Formu (EBÖ-B Formu): Araştırmada empatik beceriyi ölçmek amacıyla Empatik Beceri Ölçeği-B Formu (EBÖ-B formu) kullanılmıștır. Dökmen'in aşamalı sınıflamasına dayanılarak gelisstirilmiş olan bu ölçek, 
empatinin bilişsel bileşenlerine ağılık vermektedir. EBÖ-B Formu, geçerlilik ve güvenirlilik çalışmaları, Ankara Üniversitesi Eğitim Bilimleri Fakültesi birinci sınıf öğrencilerinden 60 kişiye ve çeşitli kurumlarda çalışan 24 psikolog aracılığıyla gerçekleştirilmiştir. Geçerlilik çalışmasında, öğrenciler ile psikologların EBÖ-B Formundan aldıkları puanlar karşılaştrılmış ve psikologlar lehine anlamlı bir fark olduğu görülmüştür $(t=8.15, p<.001)$. Aynı zamanda gerçekleştirilen başka bir geçerlik çalışmasında da EBÖ-B Formu ile Rol Alma Testi (RAT) arasında yüksek düzeyde bir ilişki ( $r=.78, p<.001)$ olduğu görülmüştür. Ölçeğin iki hafta arayla uygulaması sonucu elde edilen test tekrar test güvenirliliğinin .83 olduğu bildirilmiştir (Dökmen, 1988, 1990).

Ölçek, günlük yaşamda karşılaşılabilecek altı hipotetik durum karşısında insanların hangi tepkiyi vereceklerini belirtmeleri istenmektedir. Bireylere yöneltilen bu hipotetik durumlara ilişkin on iki tepki bulunmaktadır. Bireylerden, bu on iki tepkiden dördünü seçmeleri istenmektedir. Bireyin seçtiği tepkilere puanlama anahtarındaki puanlar verilmektedir. Bu puanların toplamı, deneğin EBÖ-B Formu'ndan aldığı toplam puanı oluşturmaktadır. Ölçekten alınabilecek en düşük puan 41 iken en yüksek puan 219، dur. Ölçekten alınan puanların yüksek olması bireylerin empatik becerisinin yüksek olduğunu göstermektedir (Dökmen, 1988, 1990).

\section{İşlem ve Uygulama}

Araştırma için gerekli izin Yozgat Valiliği il Milli Eğitim Müdürlüğü’nden alındıktan sonra, uygulama Yozgat il merkezinde Milli Eğitim Bakanlığı'na bağlı 23 ilkokul, 1 kız meslek lisesi, 4 bağımsız anaokulu olmak üzere toplam 28 okulda gerçekleştirilmiştir. Araştırmada, uygulamaya başlamadan önce araştırmacı tarafindan okul yöneticileri ve öğretmenlerle bilgilendirme görüşmeleri yapılarak araştırmanın genel amacı, gizlilik ve gönüllülük ilkeleri açıklanmıştır. Çalışmalar, gürültüden uzak ve katılımcıların birbirlerinden etkilenmelerini önlemek amacıyla geniş ve sakin sınıf ortamlarında yürütülmüştür. Uygulamalar katılımcı sayısına bağlı olarak bireysel ya da grup olarak yürütülmüştür. Uygulama sırasında katılımcılara her alt testte (Resim Oluşturma, Resim Tamamlama, Paralel Çizgiler) on'ar dakikalık süre verilerek testleri tamamlamaları sağlanmıştr. Daha sonra test materyalleri toplanmıştır. Testin uygulanması her bir oturum için açıklamalarla birlikte yaklaşık olarak elli dakika sürmüştür. Katılımcıların isteği doğrultusunda yaklaşık on dakikalık aradan sonra Empatik Beceri Ölçeği B Formu ile Genel Bilgi Formu her katılımcıya verilmiş, cevaplama işlemi tamamlandıktan sonra bu formlar da toplanarak tüm uygulamalar tamamlanmıştir.

\section{Verilerin Analizi}

Araştırma amacına uygun olarak toplanan veriler puanlanmış ve SPSS programı aracılı̆̆ıyla analiz edilmiştir. Analizlerden önce kullanılan istatistiksel tekniklerin varsayımları incelenmiştir. Field (2013) ortalamaları etkileyebilecek bir dışsal değişken olduğunda Kovaryans Analizinin uygun bir istatistiksel teknik olduğunu belirtmiştir. Bu nedenle okul öncesi ve sınıf öğretmenlerinin empatik beceri ve yaratıcılık puanları arasındaki farklııklar, gruplar yaş, cinsiyet ve medeni durum açısından farklılık gösterdiğinden Tek Değişkenli Kovaryans Analizi ile incelenmiştir. Literatürde gerçekleştirilen çok sayıda araştırma, yaşın yaratıcılık ve empatik beceri düzeylerini etkileyebilecek bir değişken olduğunu göstermesine rağmen (Abra, 1989; Alpaugh, Parham, Cole ve Birren, 1982; Ruth ve Birren, 1985; Schieman ve Gundy, 2000; Wu, Cheng, Ip ve McBride-Chang, 2005), ulaşılabilen literatürde medeni duruma ilişkin sınırlı sayıda araştırmaya erişilmiş ve bu araştırmalarda sonuçların tutarsız olduğu görülmüştür (Kolayiş ve Yiğitler, 2010; Özcan, 2012). Aynı zamanda mesleki kıdem değişkeninin kovaryant değişken olarak analize girilmemiştir. Çünkü yaş değişkeniyle yüksek düzeyde korelasyon göstermektedir $(r=.86)$. Bu nedenle analizler sadece yaş değişkeni kovaryant değişken olarak gerçekleştirmiş ancak yaş ve medeni durum değişkenleri kovaryant değişken olarak ta tekrar edilmiş ve bulgular bölümünde rapor edilen sonuçlarla aynı sonuçlara ulaşılmıştır. Tek değişkenli kovaryans analizinde yaş, kovaryant değişken sırasıyla yaratıcılığın her bir alt boyutu ve empatik beceri puanları bağımlı değişken, öğretmen branşı ise bağımsız değişken olarak analize girilmiştir. Yaratıcılığın alt boyutlarının empatik beceriyi yordayıp yordamadığı çoklu regresyon analizi ile test edilmiştir. Tek değişkenli Kovaryans Analizi ve Çoklu Regresyon Analizinin varsayımları Field (2013)'ın önerileri doğrultusunda incelenmiş ve varsayımların karşılandığı görülmüştür. Kovarnyans analizi sonuçları anlamlı çıktığında temel etki Bonferoni düzeltmesi yapılarak incelenmiştir. Verilerin test edilmesinde .05 anlamlılık düzeyi dikkate alınmıştır.

\section{Bulgular}

Bu bölümde araştırmada elde edilen bulgulara yer verilmiştir. Okul öncesi öğretmenleri ile sınıf öğretmenlerinin, yaratıcılığın alt boyutları ve empatik becerileri yaşa göre düzeltilmiş puan ortalamaları arasında anlamlı bir farklılık olup olmadığını belirlemek amacıyla bir dizi Tek değişkenli Kovaryans Analizi (ANCOVA) gerçekleştirilmiştir. Analiz sonucunda elde edilen, okul öncesi öğretmenleri ile sını öğretmenlerinin yaratıcılığın alt boyutları ve empatik becerileri puan ortalamaları, standart sapmaları yaşa göre düzeltilmiş puan ortalamaları, bu puan ortalamalarının standart hataları ve \% 95 güven aralıkları Tablo 1'de görülmektedir.

| Kastamonu Eğitim Dergisi, 27(6), 2019| 
Tablo 1. Öğretmenlerin Yaratıcılık ve Empatik Becerilerine iliş̧in Ortalamalar, Standart Sapmalar ve Düzeltilmiş Ortalamalar, Standart Hataları ve Güven Aralıkları

\begin{tabular}{|c|c|c|c|c|c|c|c|c|}
\hline \multirow{2}{*}{ Kaynak } & \multirow{2}{*}{ Öğretmen Branşı } & \multirow{2}{*}{$\mathrm{n}$} & \multirow{2}{*}{$\bar{x}$} & \multirow{2}{*}{ SS.S } & \multirow{2}{*}{$\bar{x}_{D}$} & \multirow{2}{*}{ SS.H } & \multicolumn{2}{|c|}{$\% 95$ G.A } \\
\hline & & & & & & & A.S & A.S \\
\hline \multirow{2}{*}{ Akıcılık } & Okul öncesi Öğretmeni & 665 & 332.48 & 88.39 & 333.41 & 11.16 & 331.11 & 335.71 \\
\hline & Sınıf Öğretmeni & 665 & 331.05 & 88.42 & 330.11 & 11.16 & 227.81 & 332.41 \\
\hline \multirow{2}{*}{ Orijinallik } & Okul öncesi Öğretmeni & 665 & 229.83 & 55.85 & 229.80 & 11.01 & 227.80 & 331.80 \\
\hline & Sınıf Öğretmeni & 665 & 226.83 & 88.36 & 226.86 & 11.01 & 224.86 & 228.86 \\
\hline \multirow{2}{*}{ Başlıkların soyutluğu } & Okul öncesi Öğretmeni & 665 & 55.62 & 44.74 & 55.43 &. .69 & 44.06 & 66.80 \\
\hline & Sınıf Öğretmeni & 665 & 55.34 & 55.15 & 55.52 &. .69 & 44.16 & 66.89 \\
\hline \multirow{2}{*}{ Zenginleştirme } & Okul öncesi Öğretmeni & 665 & 113.17 & 22.07 & 113.06 &. .36 & 112.35 & 113.77 \\
\hline & Sınıf Öğretmeni & 665 & 10.74 & 22.97 & 110.85 &. .36 & 110.14 & 111.55 \\
\hline \multirow{2}{*}{ Erken kapamaya direnç } & Okul öncesi Öğretmeni & 665 & 114.78 & 22.14 & 114.68 &. .44 & 113.80 & 115.55 \\
\hline & Sınıf Öğretmeni & 665 & 113.78 & 33.93 & 113.89 &. .44 & 113.02 & 114.77 \\
\hline \multirow{2}{*}{ Empatik Beceri } & Okul öncesi Öğretmeni & 665 & 1152.08 & 221.49 & 1152.23 & 33.70 & 1144.90 & 1159.55 \\
\hline & Sınıf Öğretmeni & 665 & 1137.28 & 330.62 & 1137.13 & 33.70 & 1129.80 & 1144.45 \\
\hline
\end{tabular}

Not: S.H: Standart Hata, G.A.: Güven Aralığı, A.S.: Alt Sınır, Ü.S.: Üst Sınır.

Tablo 1'e bakıldığında yaratıcılığın tüm alt boyut ve toplam puanda okul öncesi öğretmenlerin puan ortalamalarının, sınıf öğretmenlerinin puan ortalamalarından daha yüksek olduğu görülmektedir.

Tablo 2. Öğretmenlerin Branşlarına Göre Yaratıcılık ve Empatik Beceri Puanlarına iliş̧in Tek Yönlü ANCOVA Sonuçları

\begin{tabular}{lccccc}
\hline Kaynak & Kareler Toplamı & Serbestlik Derecesi & Kareler Ortalaması & $\mathbf{F}$ & $\mathbf{p}$ \\
\hline Akııılık & 231.767 & 1 & 231.767 & 3.33 & 070 \\
Orijinallik & 183.859 & 1 & 183.859 & 3.51 & 063 \\
Başlıkların Soyutluğu & .185 & 1 & .185 & .008 & 931 \\
Zenginleştirme & 104.446 & 1 & 104.446 & 15.89 & $000^{* * *}$ \\
Erken Kapamaya Direnç & 13.032 & 1 & 13.032 & 1.29 & 258 \\
Empatik Beceri & 4849.430 & 1 & 4849.430 & 6.88 & $010^{* *}$ \\
\hline
\end{tabular}

$* * p<.01, * * * p<.001$.

Tablo 2 de Tek Yönlü Kovaryans Analizi sonuçları görülmektedir. Tabloda görüldüğü gibi, ANCOVA sonuçları yaratıcılık alt boyutlarından akıclık $(F(1,127)=3.33, p=.070)$, orijinallik $(F(1,127)=3.51, p=.063)$, başlıkların soyutluğu $(F(1,127)=.008, p=.931)$ ve erken kapamaya direnç $(F(1,127)=1.29, p=.258)$ alt boyutlarından alınan yaşa göre düzeltilmiş puanlarında branşa göre anlamlı bir farklılık olmadığını göstermiştir. Ancak zenginleştirme $(F(1,127)=15.28$, $p<.001)$ alt boyutunda ve empatik beceri puanlarında $(F(1,127)=6.88, p<.05)$ branşa göre anlamlı bir farklılık olduğu belirlenmiştir. Tablo 1'de görüldüğü gibi Okul öncesi öğretmenlerinin zenginleştirme ( $\left.\bar{x}_{D}: 13.06\right)$ ve empatik beceri puanları $\left(\bar{x}_{D}: 152.23\right)$ sınıf öğretmelerinin zenginleştirme $\left(\bar{x}_{D}: 10.85\right)$ ve empatik beceri $\left(\bar{x}_{D}: 137.13\right)$ puanlarından anlamlı şekilde yüksek olduğu görülmektedir.

Tablo 3. Değişkenler Arasındaki İlişki Katsayıları, Ortalama ve Standart Sapma Değerleri

\begin{tabular}{lcccccc}
\hline & 1 & 2 & 3 & 4 & 5 & 6 \\
\hline 1. Akııılık & - & & & & & \\
2. Orijinallik & $.45^{* *}$ & - & & & & \\
3. Başlıkların soyutluğu & .10 & $.19^{*}$ & - & & & \\
4. Zenginleştirme & .17 & $.32^{* *}$ & $.19^{*}$ & - & & \\
5. Erken kapamaya direnç & -.01 & $.19^{*}$ & .09 & $.9^{* *}$ & - & \\
6. Empatik Beceri & $.35^{* *}$ & $.62^{* *}$ & $.59^{* *}$ & $.51^{* *}$ & $.31^{* *}$ & - \\
Ort. & 31.76 & 28.33 & 5.48 & 11.95 & 14.28 & 144.68 \\
\hline SS & 8.41 & 7.34 & 4.93 & 2.83 & 3.19 & 27.38 \\
\hline
\end{tabular}

${ }^{*} p<.05, * * p<.01$. 
Tablo 3'de görüldüğü gibi, yaratıcılığın alt boyutlarından akıcılık ile başlıkların soyutluğu $(r=-.10, p>.05)$, zenginleştirme $(r=.17, p>.05)$ ve erken kapamaya direnç $(r=-.01, p>.05)$ arasında istatistiksel olarak anlamlı düzeyde bir ilişki bulunmamaktadır. Ancak orijinallik $(r=.45, p<.01)$ ve empatik beceri $(r=.35, p<.01)$ arasında orta düzeyde bir ilişki olduğu görülmektedir. Orijinallik başlıkların soyutluğu $(r=.19, p<.05)$ ve erken kapamaya direnç $(r=.19, p<.05)$ ile düşük düzeyde ilişki gösterirken, zenginleştirme $(r=.32, p<.01)$ ile orta düzeyde ve empatik beceri $(r=.62, p<.01)$ ile yüksek düzeyde ilişki göstermektedir. Başlıkların soyutluğu erken kapamaya direnç ile ilişki göstermezken $(r=.09, p>.05)$, zenginleştirme ile $(r=.19, p<.05)$ düşük düzeyde ve empatik beceri $(r=.59, p<.01)$ ile yüksek düzeyde ilişki göstermektedir. Benzer şekilde zenginleştirme erken kapamaya direnç $(r=.29, p<.01)$ ile düşük düzeyde ilişki gösterirken empatik beceri $(r=.51, p<.01)$ ile yüksek düzeyde ilişki göstermektedir. Son olarak erken kapamaya direnç ile empatik beceri $(r=.51$, $p<.01)$ arasında yüksek düzeyde ilişki olduğu görülmektedir.

Tablo 4. Yaratıcılığın alt boyutlarının empatik beceriyi yordayıp yordamadığına ilişkin standart çoklu regresyon analizi sonuçları

\begin{tabular}{lccccc}
\hline & $\boldsymbol{B}$ & $\boldsymbol{S h}$ & $\boldsymbol{B}$ & $\boldsymbol{t}$ & $\boldsymbol{p}$ \\
\hline Sabit & 28.61 & & & 3.47 & .001 \\
Akıcılık & .69 & .17 & .21 & 3.99 & $.000^{* * *}$ \\
Orijinallik & 1.23 & .21 & .33 & 5.91 & $.000^{* * *}$ \\
Başlıkların Soyutluğu & 2.73 & .27 & .49 & 10.09 & $.000^{* * *}$ \\
Zenginleştirme & 2.31 & .49 & .24 & 4.68 & $.000^{* * *}$ \\
\hline Erken Kapamaya Direnç & 1.17 & .42 & .14 & 2.79 & $.006 * *$ \\
\hline
\end{tabular}

${ }^{* *} p<.01, * * * p<.001$

Tablo 4 de yaratıcılığın alt boyutlarının empatik beceriyi yordayıp yordamadığına ilişkin standart çoklu regresyon analizi sonuçları görülmektedir. Yapılan çoklu regresyon analizinde, yaratıcılı̆̆ın alt boyutlarııın tamamının empatik beceriyi yordadığı görülmüştür $\left(F(5,124)=69.01, p<.001, R=.858, R^{2}=.736, R^{2}{ }_{\text {adj }}=.725\right)$. Tablo 4'de görüldüğü gibi akıcılık ( $\beta=.21, t=3.99, p<.001)$, orjinallik $(\beta=.33 t=5.91, p<.001)$, başlıkların soyutluğu $(\beta=.49, t=10.09, p<.001)$, zenginleştirme $(\beta=.24, t=4.68, p<.001)$ ve erken kapamaya direnç $(\beta=.14, t=2.79, p<.01)$ alt boyutları empatik beceriyi olumlu yönde yordamaktadır. Yaratıcılığın alt boyutlarının tamamının toplam varyansa katkısının yaklaşık olarak \%73 olduğu görülmektedir. Başka bir ifadeyle empati puanlarındaki pozitif yönde bir birimlik artışın yaklaşık olarak \% 73'ü bu örneklemde yaratıcılık puanlarındaki bir birimlik artışla açıklanabilmektedir.

\section{Sonuçlar ve Tartışma}

Okul öncesi öğretmenleri ile sınıf öğretmenlerinin yaratıcılıkları ile empatik becerilerinin incelenmesi amacıyla yapılan bu araştırmanın elde edilen sonuçlar araştırma problemleri çerçevesinde sırayla aşağıda tartışımıştır:

ANCOVA sonuçlarına göre yaratıcılı̆ıı akıcılık, orijinallik, başlıkların soyutluğu ve erken kapamaya direnç alt boyutlarından alınan yaşa göre düzeltilmiş puanlarında branşa göre anlamlı bir farklılık olmadığı görülmüştür. Ancak zenginleştirme alt boyutunda ve empatik beceri puanlarında branşa göre anlamlı bir farklılık gözlemlenmiştir. Okul öncesi öğretmenlerinin zenginleştirme $\left(\bar{x}_{D}: 13.06\right)$ ve empatik beceri puanları ( $\left.\bar{x}_{D}: 152.23\right)$, sınıf öğretmelerinin zenginleştirme $\left(\bar{x}_{D}: 10.85\right)$ ve empatik beceri $\left(\bar{x}_{D}: 137.13\right)$ puanlarından anlamlı şekilde yüksek bulunmuştur. Bu sonuçlara göre okul öncesi öğretmenlerinin sınıf öğretmenlerine göre daha yaratıcı ve daha empatik olduğu görülmektedir. Bu sonucun okul öncesi öğretmenlerinin lisans programlarındaki farklılaşmadan kaynaklandığı düşünülebilir.

Yaratıcılığın alt boyutlarından akıcılık ile başlıkların soyutluğu, zenginleştirme ve erken kapamaya direnç arasında istatistiksel olarak anlamlı düzeyde bir ilişki bulunmamıştır. Ancak orijinallik ile empatik beceri arasında $(r=.35)$ orta düzeyde bir ilişki bulunmuştur. Orijinallik, başlıkların soyutluğu ve erken kapamaya direnç $(r=.19)$ ile düşük düzeyde ilişki gösterirken, zenginleştirme ile ( $r=.32)$ orta düzeyde ve empatik beceri ile $(r=.62)$ yüksek düzeyde ilişki gösterdiği görülmüştür. Başlıkların soyutluğu erken kapamaya direnç ile ilişki göstermezken, zenginleştirme $(r=.19)$ ile düşük düzeyde ve empatik beceri ( $r=.59)$ ile yüksek düzeyde ilişki göstermiştir. Benzer şekilde zenginleştirme, erken kapamaya direnç $(r=.29)$ ile düşük düzeyde ilişki gösterirken empatik beceri ile $(r=.51)$ yüksek düzeyde ilişki göstermiştir. Son olarak erken kapamaya direnç, empatik beceri ile $(r=.31)$ düşük düzeyde ilişki göstermiştir.

Yapılan çoklu regresyon analizinde, yaratıcılı̆ıın alt boyutlarının tamamının empatik beceriyi yordadığı görülmüştür. Akıcılık, orjinallik, başlıkların soyutluğu, zenginleştirme ve erken kapamaya direnç alt boyutları empatik beceriyi olumlu yönde yordamaktadır. Yaratıcılığın alt boyutlarının tamamının toplam varyansa katkısı yaklaşık olarak \%73 olarak | Kastamonu Eğitim Dergisi, 27(6), 2019| 
belirlenmiştir. Başka bir ifadeyle empati puanlarındaki pozitif yönde bir birimlik artş̧ı yaklaşık olarak \% 73’ ü bu örneklemde yaratıcılık puanlarındaki bir birimlik artş̧la açıklanabilmiştir. Yapılan başka araştırmalarda da benzer sonuçlar elde edilmiştir. McConnell ve LeCapitaine tarafindan, öğretmenlere verilen yaratıcılık eğitiminin, öğrencilere verilen empatik yanıt olarak öğretmen ve öğrenci tarafindan algılanan empati üzerindeki etkisini araştırmak amacıyla yaptıkları çalışma sonucunda, deney grubunun puanları, kontrol grubunun puanları ile karşılaştrıldığında öntest ve sontest arasında istenilen öğretmen davranışlarının göstergesinde anlamlı derecede yüksek puanlar elde etmişlerdir. Bu veriler ayrıca öğrencilerin ifade ettiği gibi yaratıcılık eğitiminin, öğretmen empatisi üzerinde pozitif bir etkiye sahip olduğunu da göstermiştir (McConnell ve LeCapitaine, 1988). Carlozzi, Bull, Eells ve Hurlburt (1995)'ın, üniversite mezunu 56 kişi üzerinde empati ile yaratıcılık ve dogmatizm arasındaki ilişkinin incelenmesi amacıyla yaptıkları araştırma sonucunda, (daha yaratıcı bireylerin, daha empatik oldukları yönündeki önceki araştırma bulgularını destekler nitelikte) yaratıcılık ile empati puanları arasında pozitif ve yüksek bir ilişki olduğu saptamışlardır.

\section{5. Öneriler}

Okul öncesi öğretmenleri ile sınıf öğretmenlerinin yaratıcılıkları ile empatik becerilerinin incelenmesi amacıyla yapılan bu araştırmada elde edilen bulgular doğrultusunda şu önerilerde bulunulabilir;

Hem okul öncesi öğretmenlerine hem sınıf öğretmenlerine yönelik olarak yaratıcılık eğitimi programları düzenlenebilir. Aynı şekilde her iki branştaki öğretmenlere yönelik olarak empati eğitimi programları düzenlenebilir. Sınıf öğretmenliği lisans programlarına yaratıcılık ve geliştirilmesi, drama vb. dersler konulabilir. Bundan sonra yapılacak araştırmalarda okul öncesi öğretmenlerinin ve sınıf öğretmenlerinin, yaratıcılıklarının zamana bağlı olarak değişimi incelenebilir, boylamsal araştrmalar düzenlenebilir.

\section{Kaynakça}

Abra, J. (1989). Changes in creativity with age: Data, explanations, and further predictions. The International Journal of Aging and Human Development, 28(2), 105-126. doi:10.2190/EOYT-K1YQ-3T2T-Y3EQ

Alpaugh, P. K., Parham, I. A., Cole, K. D. \& Birren, J. E. (1982). Creativity in adulthood and old age: An exploratory study. Educational Gerontology, 8(2), 101-116. doi:10.1080/0380127820080202

Altın, B. (2010). İlköğretimde görevli öğretmenlerin örgütsel bağlılıklarıyla yaratıcılıkları ilişkisi. Yayınlanmamış yüksek lisans tezi, Maltepe Üniversitesi. İstanbul.

Aslan, E. (2001). Torrance Yaratıcı Düşünce Testi'nin Türkçe versiyonu. Marmara Üniversitesi Atatürk Eğitim Fakültesi Eğitim Bilimleri Dergisi, 14, 19-40.

Aslan, A. E., \& Puccio, G. J. (2006). Developing and testing a Turkish version of Torrance's Tests of Creative Thinking: A study of adults. The Journal of Creative Behavior, 40, 163-178.

Broinowski, I. (2002). Creative childcare practice: Program design in early childhood. Pearson Education Australia: Pty Ltd.

Bronson, J., \& Schaub, N. (1996). Poetry as a healing experience for teams. (ERIC Document Reproduction Service No. ED 416 051), 54-57

Butcher, J. L., \& Niec, L. N. (2005). Disruptive behaviors and creativity in childhood: The importance of affect regulation. Creativity Research Journal, 17, 181-193.

Carlozzi, A. F., Bull, K. S., Eells, G. T., \& Hurlburt, J. D. (1995). Empathy as related to creativity, dogmatism, and expressiveness. The Journal of Psychology: Interdisciplinary And Applied, 129(4), 365-373.

Cengizhan, S. (1997). Üniversite öğretim elemanlarının yaratıcılık kapasitelerinin değerlendirilmesi. Yayımlanmamış yüksek lisans tezi. Marmara Üniversitesi, İstanbul.

Çetingöz, D. (2002). Okul öncesi eğitimi öğretmenliği öğrencilerinin yaratıcı düşünme becerilerinin gelişiminin incelenmesi. Yayımlanmamış yüksek lisans tezi. Dokuz Eylül Üniversitesi, İzmir.

Dökmen, Ü. (1996). İletişim çatışmaları ve empati. İstanbul: Sistem Yayıncılık.

Dökmen, Ü. (1988). Empatinin yeni bir modele dayanılarak ölçülmesi ve psikodrama ile geliştirilmesi. Ankara Üniversitesi, Eğitim Bilimleri Fakültesi Dergisi, 2(1-2), 155-190.

Erlendsson, J. (1999). The role of creativity, University of Iceland, http://www.hi.is/ joner/eaps/cq_cr04.htm

Field, A. P. (2013). Discovering statistics using IBM SPSS statistics: and sex and drugs and rock " $n$ " roll (4. bs.). Los Angeles: Sage.

Fishkin, A. S., Cramond, B., \& Olszewski-Kubilius, P. (1999). Investigating creativity in youth: Research and methods. Cresskill, N.J: Hampton Press.

Fraenkel, J.R. \& Wallen, N.E. (2006). How to design ant evaluate research in education. (6. Baskı). New York: McGraw-Hill International Edition. 
Genç, E. (2000). Öğretmenlerde denetim odağının problem çözmeye yönelik yaratıcılıklarıyla ilişkisi. Yayımlanmamış yüksek lisans tezi. Marmara Üniversitesi, İstanbul.

Gültekin, M. (2004). Öğretme-öğrenme sürecinde yeni yaklaşımlar. Anadolu Üniversitesi Eğitim Fakültesi Dergisi, 14(1), 25-31.

Halpin, D. (2003) Hope and Education; The role of the utopian imagination. Routledge: London.

Hamza, M. K., \& Farrow, V. (fall, 2000). Yes, you can foster creativity and problem solving in your classroom. Kappa Delta Pi- Recor. 37(1), 33-35.

Kalliopuska, M. (1983) Relationship between moral judgment and empathy. Psychological Reports, 53; 575-578

Kalliopuska, M. (1992) Holistic empathy education among preschool and school children. Paper Present at the International Scientific Conference Comenius Heritage and Education of Man. March 23-27, (p. 1-20), Praque.

Kalliopuska, M. (1989). Empathy, self-esteem and other personality factors among junior ballet dancers. Perceptual and Motor Skills, 69, 12271234.

Karaçelik, S. (2009). Okul öncesi öğretmenleri ve öğretmen adaylarının yaratıcı düşünme beceri düzeylerinin incelenmesi. Yayımlanmamış yüksek lisans tezi. Muğla Üniversitesi, Muğla.

Kaufman, J. C., \& Beghetto, R. A. (2013). In praise of Clark Kent: Creative metacognition and the importance of teaching kids when (not) to be creative. Roeper Review, 35, 155-165.

Kemple, K. M., \& Nissenberg, S. A. (2000). Nurturing creativity in early childhood education: families are part of it. Early Childhood Education Journal, 28(1), 67-71.

Kolayiş, H. ve Yiğiter, K. (2010). The examination emphatic skills of the elementary and middle school physical education teachers in city of Kocaeli. http://www.iojes.net/userfiles/Article/IOJES_184.pdf adresinden erişildi.

Köksal Akyol, A. (2011). Yaratıcılık ve drama. A. Köksal-Akyol, (Ed.). Illköğretimde drama (1. bs., s. 99-116). İstanbul: Kriter Yayınları.

Kyzer, M.L. (2001). Empathy, creativity, and conflict resolution in adolescents. Unpublished doctoral dissertation, The University of Georgia, Athens.

McConnell, D. M., \& LeCapitaine, J.E. (1988). The effects of group creativity training on teachers' empathy and interactions with students. Reading Improvement, 25(4), 269-275.

Oğuzkan, Ş., Demiral, Ö., ve Tür, G. (1999). Okul öncesinde yaratıcı çocuk etkinlikleri. İstanbul: Ya-Pa Yayınları.

Öncü, T. (2003) Torrance Yaratıcı Düşünme Testleri-Şekil Testi aracılığıyla 12-14 yaşları arasındaki çocukların yaratıcılık düzeylerinin yaş ve cinsiyete göre karşılaştırılması, Ankara Üniversitesi Dil ve Tarih Coğrafya Fakültesi Dergisi, 43(1), 221-237.

Özcan, H. (2012). Hemşirelerin empatik eğilim ve empatik becerileri: Gümüşhane örneği. Gümüşhane Üniversitesi Sağlık Bilimleri Dergisi, 1(2), $61-68$.

Ruth, J.-E. \& Birren, J. E. (1985). Creativity in adulthood and old age: Relations to Intelligence, Sex and Mode of Testing. International Journal of Behavioral Development, 8(1), 99-109. doi:10.1177/016502548500800107

San, İ. (1985). Sanat ve eğitim. Yaratıcılık, sanat sorunları, kuramları ve eleştirisi-eğitimle ilişkiler. Ankara Üniversitesi Eğitim Bilimleri Fakültesi Yayınları, No: 151. ss. 12-13. Ankara.

San, İ. (2004). Sanat ve eğitim. Ankara, Ütopya Yayınevi.

Schieman, S. \& Gundy, K. V. (2000). The personal and social links between age and self-reported empathy. Social Psychology Quarterly, 63(2), 152-174. doi:10.2307/2695889

Schrader, L. A., \& Remer, P. (1980). Statue building: Helping children sculpture their feelings. Elementary School Guidance and Counseling, 15(2), 127-162. (p127-35).

Shaughnessey, J. J., Zechmeister, E. B. \& Zechmeister, J. S. (2012). Research Methods in Psychology (9th bs.). New York, NY, US: Mc-Graw Hill.

Rein, R. P. \& Rein, R. , (2000). Çocuğunuzun beceri ve yeteneklerini nasıl geliştirebilirsiniz? (Çev. : S. Göktan). Ya-pa Yayınları, İstanbul.

Torrance, E. P. (1974). The Torrance Tests of Creative Thinking-Norms-Technical Manual Research Edition-Verbal Tests, Forms A and B- Figural Tests, Forms A and B. Princeton, NJ: Personnel Press.

Torrance, E. Paul \& Goff, Kathy (1989). A quiet revolution. Journal of Creative Behavior 23(2), $136-145$.

Torrance, E.P. (1987). Teaching for creativity. In S. Isaksen (Ed.), Frontiers of creativity research (pp. 15-21). New York: Bearly Limited.

Töremen, F. (2003). Creative school and administration. Educational Sciences: Theory \& Practice, 3(1), $248-253$.

Wallace, R. R. (1998). The efects of arts education on emotional literacy. A Thesis presented to the faculty of the master of arts degre program Salem-Teikyo University, Japan.

Wu, C. H., Cheng, Y., Ip, H. M. \& McBride-Chang, C. (2005). Age Differences in creativity: Task structure and knowledge base. Creativity Research Journal, 17(4), 321-326. doi:10.1207/s15326934crj1704_3

Yavuzer, H. (1996). Çocuk psikolojisi. İstanbul: Altın Kitapları Yayınevi.

Zeytun, S. (2010). Okul öncesi öğretmenliği öğrencilerinin yaratıılık ve problem çözme düzeyleri arasındaki ilişkinin incelenmesi. Yayımlanmamış yüksek lisans tezi. Dokuz Eylül Üniversitesi, İzmir.

Data were collected by using General Information Form, Torrance Creative Thought Scale Figure Form A Test. 